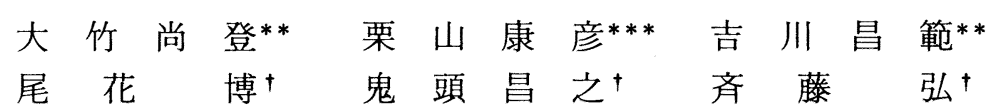

\title{
Development of Arc Discharge Plasma Apparatus for High Rate Synthesis of Diamond
}

Naoto Ohtake, Yasuhiko Kuriyama, Masanori Yoshikawa

Hiroshi Obana, Masayuki Kito and Hiroshi Saito

This paper describes the development of arc discharge plasma jet chemical vapor deposition (CVD) apparatus for the high rate synthesis of diamond. Methane and hydrogen are used as source gases. In terms of generating a stabilized plasma jet, gas flow routes of the source gases are discussed. When both methane and hydrogen are supplied from cathode nozzle, the electric discharge power varies a lot from set value, and the plasma jet becomes unstable. When methane is used as an atmospheric gas and is poured into the reaction chamber, however, the stabilized plasma jet is obtained. The methane is mixed into the plasma jet, the plasma jet is sprayed onto a cool-down substrate, and a diamond film is deposited on the substrate surface. By means of this methane atmosphere technique, a diamond film is deposited on a molybdenum substrate at the growth rate of $930 \mu \mathrm{m} / \mathrm{h}$. The crystallinity of the diamond film measures well by means of X-ray diffraction and Raman spectroscopy.

Key words: high rate synthesis, diamond, arc discharge, plasma jet CVD, diamond film, Raman spectroscopy

$$
\text { 1.はじめに }
$$

1956年に Derjaguinらによって気相成長によるダイ ヤモンド合成の成功が報告されて以来"，ダイヤモン ドの気相合成に関する研究は急速に進展した。これま でに熱フィラメントCVD法")，マイクロ波ブラズマ $\mathrm{CVD}$ 法 $^{31}$ ， E A C V D 法 ${ }^{41}$ ，直流放電プラズマCV $\mathrm{D}$ 法 ${ }^{5}$ ，高周波プラズマ $\mathrm{CVD}$ 法6)，ブラズマジェッ ト C V D 法 ${ }^{7}$ ，燃焼炎法 ${ }^{8}$ など多くの方法によってダ イヤモンドの合成が報告されている.

気相合成されたダイヤモンドは，その優れた硬さ， 熟伝導事, 電気絶縁性を生かして電子基板材料, ヒ一

* 原稿受付 平成元年6月1日. 1989年度精密工学会 春季大会学術講演会 (平成元年3月24日) にて発表

** 正会員 東京工業大学工学部（東京都目黒区大 岡山2-12-1)

*** 学生会員 果京工業大学工学部

+ 正会 貝 小野田セメント倠アイオンス事業部 （果京都江果区豊洲1-1-7）
トシンク, 切削工具, 砥粒等への適用が期待されてい る. しかし,これまでの気相合成法ではダイヤモンド の成長速度が遅く, 実用化に際しての問題点となって いる.

本研究は気相成長によるダイヤモンドの高速合成を 目的に, アーク放電プラズマジェットを用いたダイヤ モンド気相合成装置を試作し，その装置の性能を明ら かにしながら，合成されたダイヤモンド膜の性質およ び合成速度について調べたものである.

\section{2. 試作合成用アーク放電プラズマジェット 装置の構造}

本装置は, アーク放電により水素とアルゴンの混合 ガスをブラズマ状態にし，それにメタンガスを挿入し ながら冷却した基板の表面に吹きつけることによりダ イヤモンド膜を合成させるものである. アーク放電ブ ラズマジェット装置の概略図を図 1 に示す.これは直 流プラズマトーチ, 真空チャンバ, 水冷基板ホルダ, 


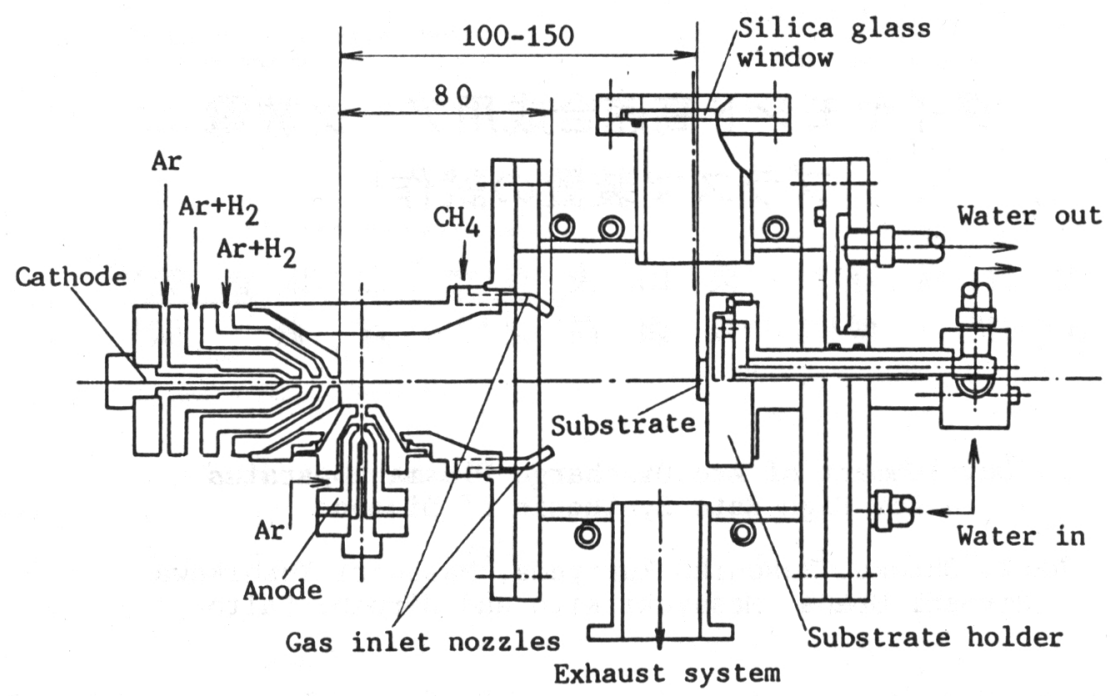

Fig.1 Structural drawing of the plasma CVD apparatus

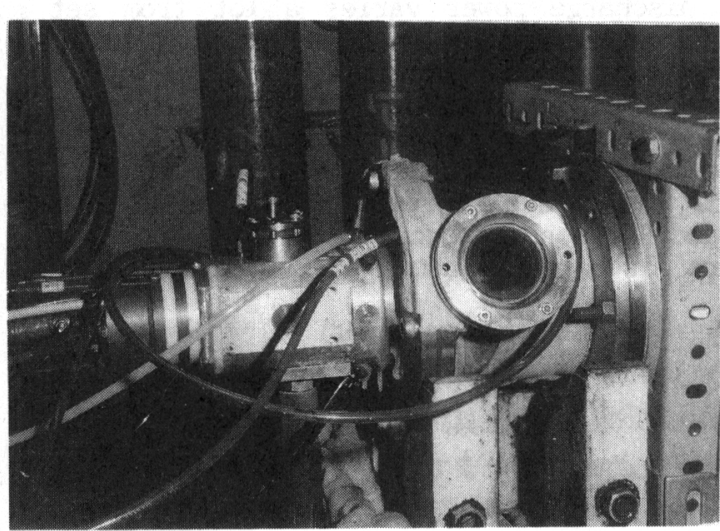

Fig.2 Over view of the apparatus

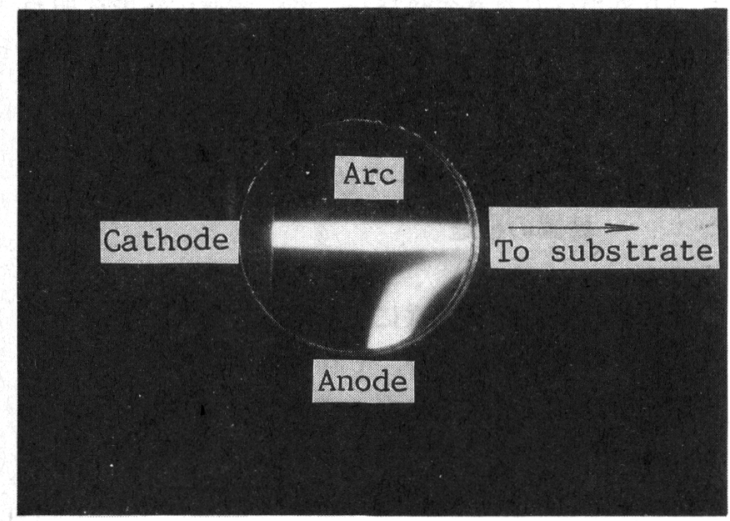

Fig. 3 Top view of the arc generated
ガス給排気系から構成されており，その外観写真を図 2 に示す.

真空チャンバは, 真空度を測定するためのポート， 合成中の状態を観察したり基板温度を測定したりする ための石英ガラス製空, および排気ポートからなる. この真空チャンバは ○リングで気密性が保たれ，また 周囲に水冷銅管を巻いて冷却されている. なお，チャ ンバの材料にはステンレス鋼が用いられている.

プラズマを発生させるトーチは, 高速で長い状態の プラズマジェットが発生するように，電極を直角に配 置してあり, $\varnothing 2.6 \mathrm{~mm}$ の陰極ノズルからガスを噴出さ せることができるようになっている. そのために, フ ラズマジェットの長さが大気中で $200 \mathrm{~mm}$ と長くなり, ブラズマ中に異種のガスを挿入してもそのガスがブラ ズマ状態になる.

陰極はタングステンからなる. 陰極部は, 内部に 3 本の独立したガス流路をもち, 先端に近い 2 流路から 原料ガスを流入し，内側の流路からアルゴンガスを流 入した.これにより，電極の消耗を防止することがで きる.

陽極は銅からなり，内部を水冷すると共に周囲にア ルゴンガスを流入することによって保護した.このよ うに電極を保護することにより，電極材料のダイヤモ ンド膜への混入を避けることができる. その他の電極 部はクロム銅からなり, 内部に冷却水を流して冷却さ れている.

罒3に上方から観察した放電の様子を示す.アーク は, 陰極ノズルからガスの噴出方向に伸びたのち, 弧 
を描いて陽極に達していることがわかる.

発生されるブラズマジェットは高温であるため,こ の中に基板を挿入すると溶けてしまう，そこで，基板 を接着した銅製の基板ホルダを水冷した，基板は軸方 向に可娌であり，軸方向の位置を陰極のノズル先端か ら100〜150 mmに変化させることができる.

基板の接着には銀ペーストを用い，接着後60分以上 大気中で乾燥させて, 基板との接着強度を高めた.

ダイヤモンド合成に用いたガスは，メタン，水素， アルゴンである.このうち, 原料ガスであるメタンと 水素のガス流量は, マスフローコントローラを用いて 制御し，アルゴンは, フロート式流量計を用いて二ー ドルバルブによって制御した。

排気は能力 $300 \mathrm{~L} / \mathrm{min}$ のロータリーポンプを用い, 内径30 mmの主排気路と内径 $3 \mathrm{~mm}$ の排気路からなる 2 系統により行った．実験前に，まず主排気路から $1 \times$ $10^{-3}$ Torr程度まで排気し，その後主排気路を閉じてバ イパスによってニードルバルブを調整しながら雾囲気 圧力を制御して，合成実験を行った。このガス排気装 置によって, 合成中の雾囲気圧力を50７60 Torrの間 で任意に設定できる.

\section{3. ガス流入経路の検討}

ダイヤモンドを合成するためには，長時間安定した プラズマジェットを発生させ，さらに基板温度をダイ ヤモンド生成に適した温度で一定に保つ必要がある.

本研究では, 原料ガスとしてメタン, およびダイヤ モンドの気相合成に必要とされる水素”を用いた。そ れに, 放電の安定及び電極の保護のためにアルゴンガ スを添加した。これらのガスのうち, 水素とメタンは 解離しやすく，放電を不安定にする原因となる．そこ で, ト一チ内のガス流入のほかに，チャンバ内へ原料 ガスを流入する 2 本のノズルを設け，その流入位置に ついて检討した.

トーチから水素とメタンガスを流入した場合, 別に 設けたノズルから水素とメタンガスを流入した場合, さらにトーチから水素を, 別に設けたノズルからメ夕 ンガスを流入した場合について, 放電電力の変動を測 定し，その結果を図4 に示す.

トーチから原料ガスを流入した (a)では出力の変動 が2.5 kW以上あり, ブラズマは非常に不安定である.

そして，30分の連続運転でノズルが溶失した。これは， メタンガスがアーク中で分解し, 内部を水冷されてい るノズル部で急冷されて, すすとなって付着したり, そのすすが脱落したりして, ガス流量が変化するため
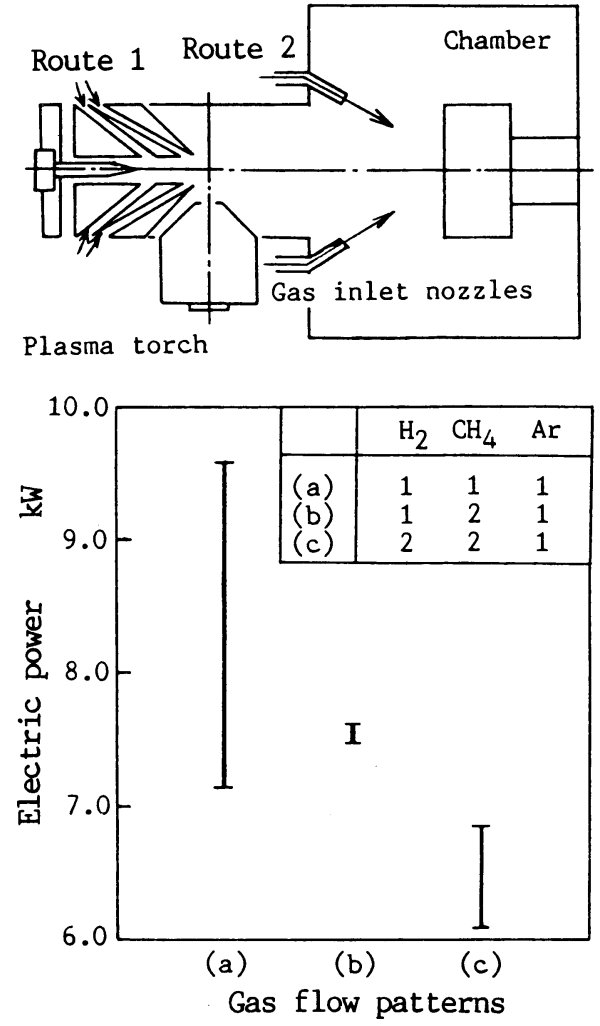

Fig. 4 Effects of gas-flow patterns on electric power stability

と考えられる.

それに対して, 水素をトーチから，メタンガスを別 に設けたノズルから流入した ( b )では, メタンガスが アーク中に入らないために, 出力変動が0.1 kW程度で, プラズマジェットは非常に安定している.

また，水素を別に設けたノズルから流入した（c）で は，（ｂ）の場合より変動が大きい。これは，ノズルか らの水素の流量が大きいために，チャンバ内部のガス の流れが乱れ，アークが安定しないためと考えられる. これらのことょり, 原料ガスの流入法として, ト一 千内から水素を, 別に設けたノズルからメタンガスを 流入するのが適切であることがわかり，以後の実験で は，（b）の方法によって行った.

\section{4. 基板温度の設定}

基板温度の測定はチャンバに取りつけた石英ガラス 製の空から光高温計により行った.この際, 基板に対 して直角方向から温度測定できないため, 補正を行つ た。また，放射率は，基板上にダイヤモンドが生成す 


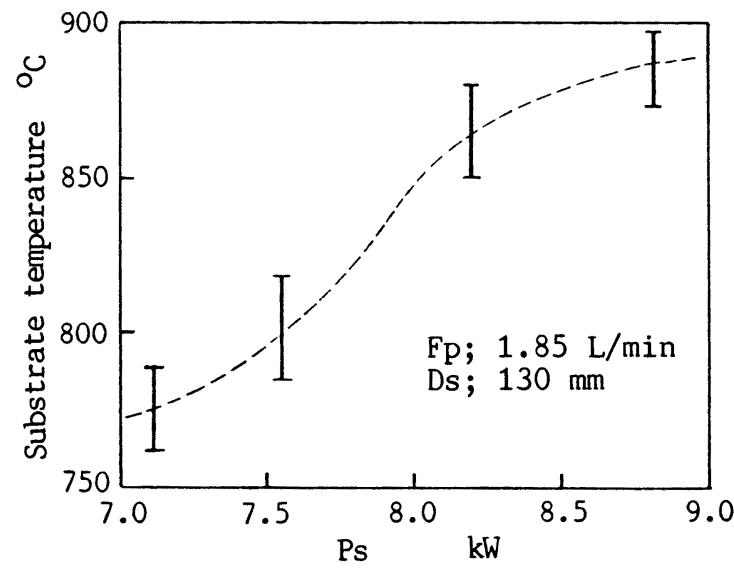

Fig. 5 Variation of substrate temperature with electric power; Ps Fp; Gas flow-rate from anode nozzle Ds; Distance from cathode nozzle to substrate

ることにより変化するので, あらかじめダイヤモンド が生成した後の基板の放射率を熱電対で校正し， 0.5 とした. そして,フフラズマ自身の発光を検出しないよ うに，合成中にプラズマを停止して，その時の基板温 度を測定し, それを合成時の基板温度とした.

基板温度はプラズマ出力, 陰極ノズルからのガス流 量, 基板位置を変えることで変化させることができる. そして, ナ゙ラズマ出力は放電電流を変えることで変化 させることができる.

出力を7 9kWで変化させたときの基板温度を図 5 に 示す. 出力が高くなるにつれて基板温度が上昇するこ とがわかる. プラズマジェットの径は, 出力が高くな るにつれて大きくなり， $8.5 \mathrm{~kW}$ 程度で基板の大きさと 等しくなる. 従って, 出力を $8.5 \mathrm{kWW上にすると,} \mathrm{フ}$ ラズマジェットの径が基板より大きくなり, ブラズマ ジェットの一部が基板にあたらなくなるため, 基板温 度の上型は小さくなる。

基板位置による基板温度の変化を四 6 に示す，基板 がノズルから $100 \mathrm{~mm}$ 程度まで近づくと，プラズマの密 度が高くなるために基板温度は急速に上昇し，それよ り近づけると基板温度の制御が困難になる. 一方, 距 離が130 mm以上になるとプラズマジェットの径が小さ くなって, 温度が700 ํ以下に低下し, ダイヤモンド 合成が難しくなる.これより合成条件として110～140 $\mathrm{mm}$ の距離が適当であると言える.

陽極のアルゴンガス流量と基板温度の関係を四 7 に 示す.アルゴンガスは電極の保謨のほかに, ブラズマ ジェットの密度を変化させる効果がある. 流量を 1.65 L/min 以下にするとプラズマジェットの径が小さくな

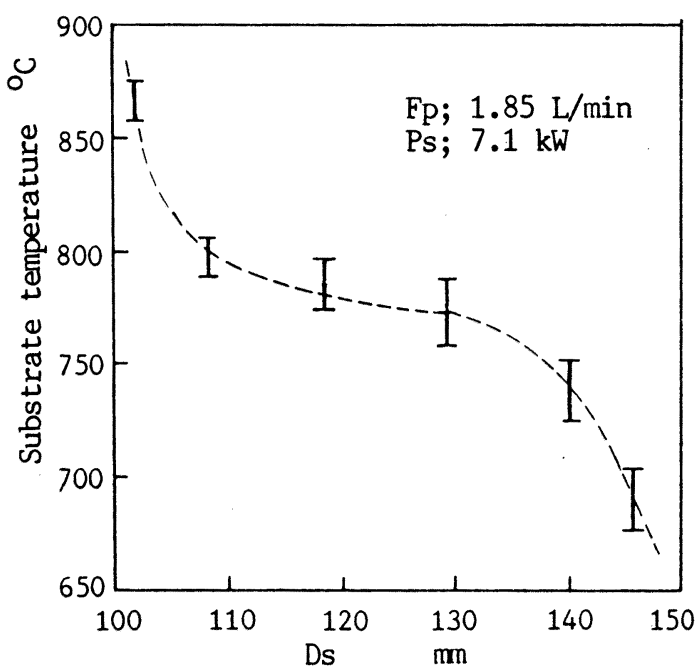

Fig.6 Variation of substrate temperature with distance from cathode nozzle; Ds

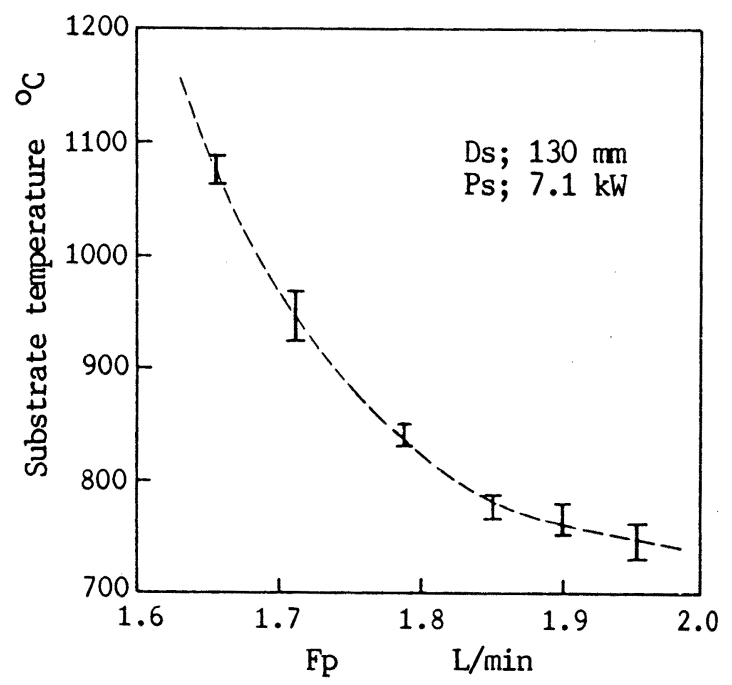

Fig.7 Variation of substrate temperature with gas flow-rate from anode nozzle; Fp

Table 1 Deposition condition

\begin{tabular}{l|c}
\hline Gas flow rate & $1.5 \mathrm{SLM}$ \\
$\mathrm{H}_{2}$ & $0.08 \mathrm{SLM}$ \\
$\mathrm{CH}_{4}$ & $7.5 \mathrm{SLM}$ \\
$\mathrm{Ar}$ & $5.3 \%$ \\
$\mathrm{CH}_{4} / \mathrm{H}_{2}$ & $90 \mathrm{~A}$ \\
Electric power & $105 \mathrm{~V}$ \\
& $25 \mathrm{kPa}$ \\
Atmospheric pressure & $110 \mathrm{~mm}$ \\
Distance from cathode & \\
nozzle to substrate & Molybdenum \\
Substrate & $10 \times 10$ \\
& $1000^{\circ} \mathrm{C}$ \\
Substrate temperature & $1 \mathrm{~h}$ \\
Deposition time &
\end{tabular}




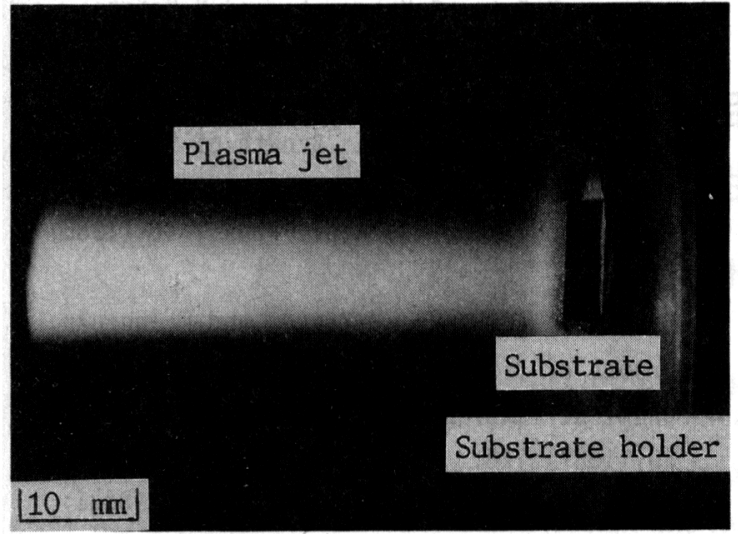

Fig. 8 Plasma jet state during diamond deposition



(a) Surface



(b) Cross-section

Fig.9 SEM photographs of (a) surface and (b) cross-sectional view of the obtained diamond film

つて密度が増し，基板温度は $1100^{\circ} \mathrm{C}$ 以上に上昇し，ダ イヤモンドは合成できなくなる.

これらのことにより, 本装置では, プラズマ出わ, 陰極ノズルからのガス流量, 基板位置を変化させるこ とによって, 基板温度を $700 \sim 1100{ }^{\circ} \mathrm{C}$ 間の任意の温度 に設定できることがわかった.

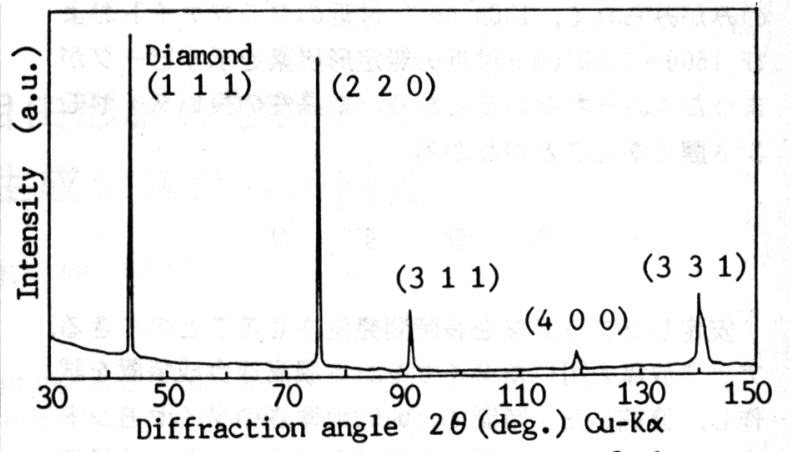

Fig.10 X-ray diffraction pattern of the diamond film shown in Fig.9

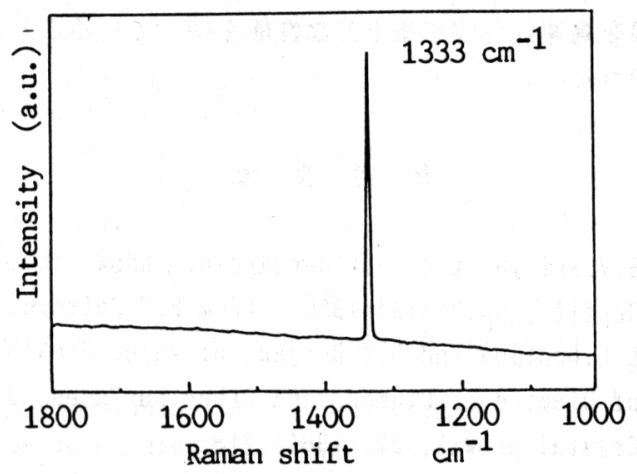

Fig.11 Raman spectrum of the diamond film shown in Fig.9

\section{5. ダイヤモンド膜の合成}

本装置を用いてモリブデン基板上にダイヤモンド膜 の合成を行った．その時の合成条件を表 1 に, 合成中 の様子を悹から镜察した写真を図8に示す.プラズマ ジェットが基板に吹き付けられ, 基板表面にダイヤモ ンドが析出している様子がわかる.

連続した 1 時間の合成で得られたダイヤモンド膜の 表面, および基板から剥離したダイヤモンド膜の破断 面のS E M 観察写真を図 9 に示す。表面凹凸の激しい 膜であるが，ダイヤモンドの自形を表す三角形を示す 多くの面から成っていることがわかる.この膜の最大 厚さは0.93 mmであり, 1 時間に0.93 mmの成長速度を 得られることがわかる.この值はこれまでに報告され ている値 ${ }^{7}$ の 5 倍以上の値であり, 本装置によるダイ ヤモンド膜の合成を高速合成と称してよいと考える.

膜の X 線回折結果を四 10 に, ラマン分光分析結果 を図 11 に示す.X線回折結果にはダイヤモンドのピ 一クのみがみられ, 合成された物質はダイヤモンドで あると同定される. また,この膜のラマン分光分析結 果では1333 $\mathrm{cm}^{-1}$ のダイヤモンドを示す鋭いピーク 
のみがみられて, $1360 \mathrm{~cm}^{-1}$ 付近のグラファイトおよ び 1500 1600 $\mathrm{cm}^{-1}$ 付近の無定形炭素を示すピークが まったくみられないことから，結晶性の良いダイヤモ ンド膜であることがわかる.

$$
\text { 6. むす び }
$$

安定したブラズマを長時間発生させることのできる, アーク放電を用いたダイヤモンド膜高速合成装置を試 作し, 連続した 1 時間で, $0.93 \mathrm{~mm} /$ 厚さのダイヤモンド 膜を合成した．この膜は表面凹凸が激しいが，結晶性 のよい膜であることがわかり, 本装置は, ダイヤモン ド膜を高速に合成する十分な性能を持っていることが わかった.

\section{参 考 文 献}

1) B.V.Spityn and B.V.Derjaguin: USSR Inv. Certif., No.339134(1956). From B.V.Spitsyn, L.L.Bouilov and B.V.Derjaguin: Vapor Growth of Diamond on Diamond and Other Surfaces, J. Crystal Growth, 52,(1981) 219.

2) S.Matsumoto, Y.Sato, M.Kamo and N.Setaka: Vapor Deposition of Diamond Particles from Methane, Jpn.J.Appl.Phys., 17, (1982) L183.
3) M.Kamo, Y.Sato, S.Matsumoto and N.Setaka: Diamond Synthesis from Gas Phase in Microwave Plasma, J.Cryst.Growth, 62,(1983) 642.

4) A.Sawabe and T. Inuzuka: Growth of Diamond Thin Films by Electron Assisted Chemical Vapor Deposition, J. Appl. Phys., 46,(1985) 146.

5) K.Suzuki, A.Sawabe, H.Yasuda and T. Inuzuka: Growth of Diamond Thin Films by dc Plasma Chemical Vapor Deposition, Appl.Phys.Lett., 50, (1987) 728.

6) S. Matsumoto, M. Hino and T. Kobayashi: Synthesis of Diamond Films in a rf Induction Thermal Plasma, Appl. Phys.Lett., 53,(1987) 737.

7) K.Kurihara, K.Sasaki, M.Kawarada and N. Koshino: High Rate Synthesis of Diamond by dc Plasma Jet Chemical Vapor Deposition, App 1.Phys.Lett., 52,(1988) 6.

8）広瀬洋一，三ツ泉 誠：燃焼炎を利用した大気中 でのダイヤモンド合成，ニューダイヤモンド，4, 3, (1988) 34 .

9) S.A.Solin and A.K.Ramdas: Raman Spectrum of Diamond, Phys. Rev., B1,(1970) 1687.

正誤 表

\begin{tabular}{|c|c|c|c|c|c|c|}
\hline 巻 & 号 & ページ & 欄 & 行 & 誤 & 正 \\
\hline 55 & 5 & $\begin{array}{l}916 \\
918\end{array}$ & $\begin{array}{l}\text { 右 } \\
\text { 右 }\end{array}$ & $\begin{array}{c}\downarrow 7 \\
\text { 式 (14) } \\
\text { 式 (15) } \\
\text { 式 (16) }\end{array}$ & 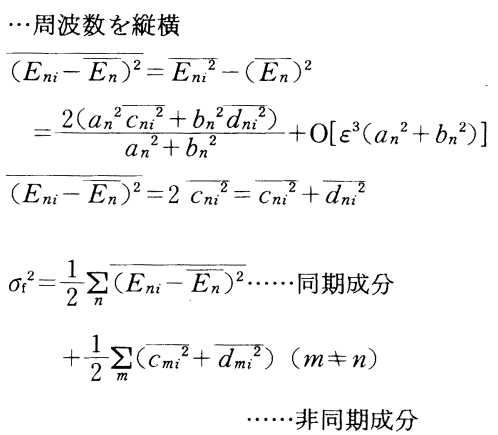 & 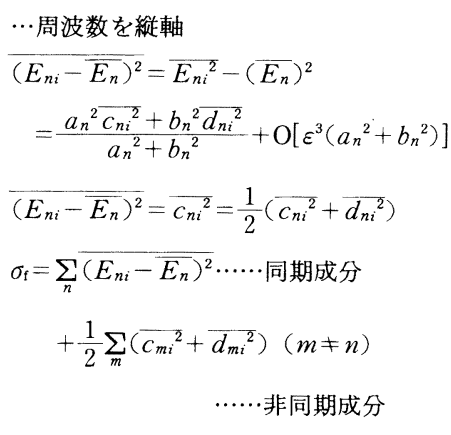 \\
\hline
\end{tabular}

